\title{
Modern trends in development of alternative powertrain systems for non-road machinery
}

ARTICLE INFO

Received: 29 July 2021

Revised: 11 August 2021

Accepted: 18 August 2021

Available online: 16 September 2021
The main goal of the paper is to review available alternative powertrain technologies for non-road machinery. Based on that, to propose adequate classification and recognise main trends within this area. The paper presents various powertrain propositions alternative to internal combustion engine and solely mechanical powertrain developed by manufacturers over a course of years. The article explains actual legislative situation regarding environmental challenges connected to the powertrain solutions and reiterates the need for development in that area. Both commercially available and only presented at fairs or at early development stages solutions have been analysed. Depending on the load conditions and work patterns multiple benefits as well as challenges to the reviewed concepts have been discussed. Certain classification of existing powertrain solutions have been proposed taking into account its design and functionality.

Key words: powertrain technology, alternative drive, hybrid, agricultural, construction

This is an open access article under the CC BY license (http://creativecommons.org/licenses/BY/4.0/)

\section{Introduction}

Increasingly stringent environmental protection laws and reduction of fossil fuels dependency are the main objectives of modern economies. Development of new powertrain systems faces two major challenges. First is to increase working parameters of the powertrain with simultaneous reduction of fuel consumption and the second to stay compliant with current environmental protection laws. Very often these two conditions are contradictory to each other and are difficult to fulfill [1-4].

Continuous decrease of $\mathrm{CO}_{2}$ emissions thus reduction of fuel consumption are the main drivers for search of new powertrain solutions. Some countries have introduced specific limits and presented specific laws focused on reduction $\mathrm{CO}_{2}$ emission. The European Union also have introduced first $\mathrm{CO}_{2}$ limit standards for example for passenger cars in 2009. In 2015 this limit was set at $130 \mathrm{~g} / \mathrm{km}$, and in 2020 at $95 \mathrm{~g} / \mathrm{km}$ as an average emission calculated for new car fleet $[5,6]$.

For non-road machinery new Stage $\mathrm{V}$ emissions standards have been phased in already in 2018 in European Union. These regulations limit emission of $\mathrm{CO}, \mathrm{HC}, \mathrm{NO}_{\mathrm{x}}, \mathrm{PM}$ and PN $[7,8]$.

Multiple technologies have been put in place over last years to already meet previous limits, especially on $\mathrm{NO}_{\mathrm{x}}$ and PM. Namely, high pressure common rail injection, cooled exhaust gas recirculation, diesel oxidation catalyst, selective catalytic reduction and exhaust particulate filter $[9,10]$.

Use of electric, electrified or hybrid drives can also significantly increase efficiency of powertrains and therefore reduce emissions. Moreover, introduction of mentioned solutions may expand vehicle flexibility and create new functionalities. Together with fast development of machine automatization, precision farming and use of satellite positioning system for farming operation continuously increase interest in alternative drives. Mainly due to ease control of speed and torque and due to system simplification in comparison to mechanical or hydraulic solutions $[11,12]$.
Starting at mid 1950s manufacturers have already tried alternative powertrain solutions, for instance: IH Farmall 450 with additional electric generator for power output or Allis-Chalmers with fuel cell powered tractor (Fig. 1). Later in 1970s, Terex presented Titan mining dump truck with diesel-electric powertrain. Mentioned examples of alternative solutions have not created significant demand and have been abandoned for next decades [13].

\begin{tabular}{|c|c|c|c|c|c|}
\hline No. & Year & Manufacturer & Model & Alternative drive type & Energy store \\
\hline 1 & 1954 & IH Farmall 450 & IH ElectrAll & Electrified components & NO \\
\hline 2 & 1959 & Allis-Chalmers & Fuel cell & FCEV & NO \\
\hline 3 & 1974 & Terex & Titan & Diesel-electric & No \\
\hline 4 & 1998 & Eltrac/Schmetz GmbH & E135 & Diesel-electric & NO \\
\hline 5 & 2005 & IH Case & ProHybrid EECVT & HEV & YES \\
\hline 6 & 2007 & John Deere & 7430/7530 E premium & Electrified components & NO \\
\hline 7 & 2008 & Caterpillar & D7E & Diesel-electric & No \\
\hline 8 & 2009 & Belarus & 3023 & Diesel-electric & NO \\
\hline 9 & 2010 & Agco & ElectRoGator 1386 & Diesel-electric & No \\
\hline 10 & 2011 & New Holland & $\mathrm{NH} 2$ & FCEV & YES \\
\hline 11 & 2011 & John Deere & $6210 \mathrm{RE}$ & Electrified components & NO \\
\hline 12 & 2011 & Rigitrac & EWD 120 & Diesel-electric & No \\
\hline 13 & 2012 & Komatsu & HB205-1 & HEV & YES \\
\hline 14 & 2013 & John Deere & $644 \mathrm{~K}$ & Diesel-electric & NO \\
\hline 15 & 2013 & Merlo & 40.7 Hybrid & PHEV & YES \\
\hline 16 & 2013 & Fendt & $\mathrm{x}$ Concept & Electrified components & NO \\
\hline 17 & 2014 & Belaz & 75710 & Diesel-electric & NO \\
\hline 18 & 2015 & Multi Tool Track & N/A & REX & YES \\
\hline 19 & 2016 & Claas & Arion 650 hybrid & HEV/electrified auxiliaries & YES \\
\hline 20 & 2016 & John Deere & SESAM & BEV & YES \\
\hline 21 & 2016 & Kramer & $5055 \mathrm{e}$ & BEV & YES \\
\hline 22 & 2016 & ZF & Terra + & Electrified components & No \\
\hline 23 & 2017 & Fendt & $\mathrm{e} 100$ & BEV & YES \\
\hline 24 & 2017 & Farmtrac & $26 \mathrm{E}$ & BEV & YES \\
\hline 25 & 2018 & John Deere & GridCON & Electric drive & No \\
\hline 26 & 2019 & Steyr & Konzept & PHEV & NO \\
\hline 27 & 2019 & Rigitrac & SKE 50 & BEV & YES \\
\hline 28 & 2019 & John Deere & IRE & BEV & YES \\
\hline 29 & 2019 & John Deere & Joker & BEV & YES \\
\hline 30 & 2019 & John Deere & 8370 eAutoPowr & Electrified components & NO \\
\hline 31 & 2020 & Case & $580 \mathrm{EV}$ & BEV & YES \\
\hline 32 & 2020 & $\mathrm{JCB}$ & $525-60 \mathrm{E}$ & $\mathrm{BEV}$ & YES \\
\hline 33 & 2021 & John Deere & E-power backhoe & BEV & YES \\
\hline
\end{tabular}

Fig. 1. List of selected alternative powertrain solutions for non-road machinery

New approach to the alternative powertrain solutions appeared again in early 2000s. In 1998 Schmetz GmbH created test diesel-electric powertrain based on New Holland tractor. Later, with initiative of Universities in Munich 
and Regensburg, together with AGCO, Wiedemann and Fraunhofer-Geselschaft, project MELA (Mobile Electrische Leistungs- und Antriebstechnik) have started with goal to create high efficiency electric components for dieselelectric powertrains [14].

Similarly, project TEAM (Entwicklung von Technologien fur energiesparende Antriebe mobiler Arbeitmaschinen) created with RWTH University in Aachen and Universities in Karlsruhe and Dresden together with many manufacturers, e.g. AGCO, Claas, Deutz, Wirtgen, CAT, Liebherr, Rexroth and others resulted in works on high speed electric motors and electric components for non-road machinery drives [14].

Since mid 2000s more companies experimented with different types of alternative powertrains, either prototype ones like Belarus with its diesel-electric model 3023, Case with hybrid-electric ProHybrid EECVT or large-scale production like John Deere 7430/7630 E Premium with electrified auxiliaries [13-16].

From 2010s onwards increasingly higher interest in alternative powertrains have been seen. More large companies like John Deere, New Holland or AGGO would create prototypes and large-scale production machines. However, also smaller companies like Rigitrack, Merlo or Farmtrack have started creating its own solutions $[12,13,17]$.

Examples of the alternative powertrains selected by author can be seen in Fig. 1. List of selected alternative powertrain solutions for non-road machinery.Fig. 1. List of selected alternative powertrain solutions for non-road machinery

The year of presentation, manufacturer and model as well as type of powertrain have been indicated to present the variety of solutions developed by the manufacturers.

\section{Alternative powertrain solutions}

Alternative powertrain solutions can vary and encompass different concepts from electrified auxiliary power outputs, diesel-electric and diesel-hydraulic solutions through many hybrid layouts to the battery-electric, fuel cell-electric and many other variations.

Classification and unified definitions of this solutions its needed to understand the differences between them as well as their advantages and challenges for the practical use of them. More in-depth systematization of alternative powertrain solutions for non-road machinery will be presented in this chapter. Proposed classification is author's approach to the subject.

To determine different definitions for alternative powertrain solutions, first definition of the opposite: the conventional drive needs to be clarified. For the non-road machinery traditionally, the conventional powertrain would consist of internal combustion engine and mechanical or hydromechanical transmission.

Proposition for non-road machinery classification can be seen on Fig. 2.

\subsection{In-series drive}

In series drive is the powertrain architecture where prime mover and drive components are connected to each other in a way that one propels the next one and transfers the torque to the driving wheels. For non-road machinery prime mover would typically be diesel internal combustion engine (ICE).

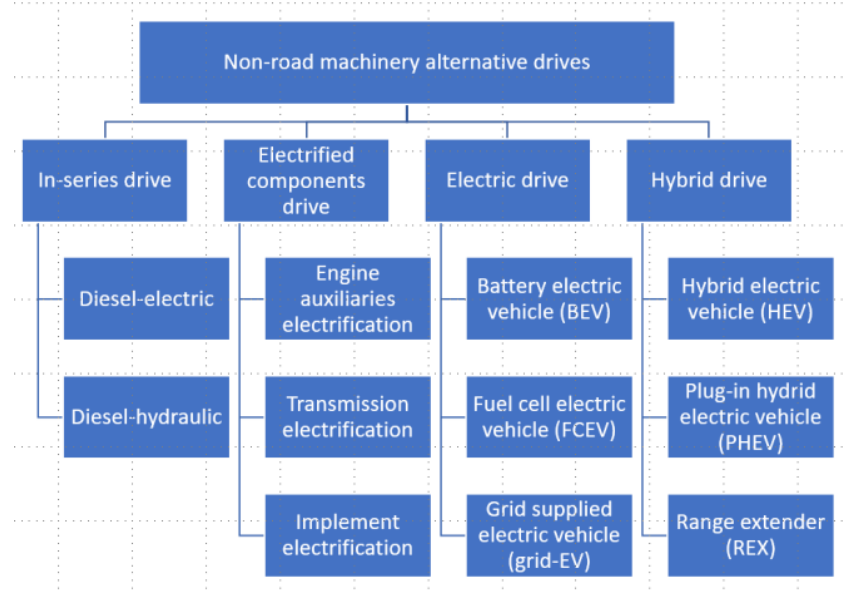

Fig. 2. Non-road machinery alternative drive classification

Fist type of the in-series drive is the diesel-electric drive. In this solution diesel drives the electric generator and sends the electric power straight to the electric motor and further to the transmission or final drive. Alternatively, electric energy can be sent to multiple electric motors mounted on driving axles or even directly on driving wheels. This solution is well known and used within marine, rail and other industries.

The second type of in-series drive used in non-road machinery is the diesel-hydraulic drive. In this solution prime mover supplies torque to the hydraulic pump or pumps and sends the hydraulic power to the hydraulic motors. Similarly, to the previous solution hydraulic motor can drive the gearbox, axles or directly driving wheels. Powertrain of this type is also well known and widely used for instance in agricultural sprayers, telehandlers, harvesting machines and others.

Main advantage of both those solutions is that transmission or gearbox of any type in not required. However, quite often the transmission is used anyway to increase the powertrain possibilities.

It is worth to mention this solution cannot be considered as a hybrid drive. Mainly because it lacks an energy store of any form or source of power other than mainly diesel in this case. In other words, the vehicle cannot be operated if the prime mover is stopped, unlike to a hybrid drives [4].

\subsection{Electrified components drive}

This alternative powertrain type is sometimes considered to be the first step to the machine hybridization, namely micro-hybridization. Main idea behind the solution is to integrate electric generator within certain areas of the existing, mainly classical powertrain, e.g. on a flywheel. Generated electrical energy can be used to supply components within the machine itself or be sent to the attached implements.

First type of this solution deals with engine auxiliaries electrification. Some systems components within the internal combustion engine (ICE) can be successfully driven by electric motors instead of mechanical or hydraulic drives. This increases ease of control and expands the possibility 
for new functionalities, e.g. radiator fan reverse for cleaning purposes.

Next type is the transmission electrification. Main objective of this solution is to increase the efficiency and sensitivity of hydraulic or mechanic-hydraulic transmission. Higher efficiency of electric generator and motor successfully increases total efficiency of the transmission in comparison to the use of hydraulic pump and hydraulic motor [3].

The third solution is the implement electrification. Similarly, to the previous two drives, mechanical or hydraulic transmission of energy to the implement can be change for the electric energy. In order to achieve that generator needs to be placed somewhere on a driveline and be able to supply external receivers connected to the machine. Typically, that would be fly wheel or side generator.

In practice, those three solutions can be incorporated within one machine and use common generator to satisfy those three types of needs.

\subsection{Electric drive}

Purely electric drive cab be another solution for the nonroad machinery. In this case power transferred to the driving wheels comes from electric motor and goes either through some sort of transmission or final drive or goes directly to the driving hubs. Electric drive gives wide possibilities for torque and speed control as well as ease of operation.

Electric energy supplied to the electric motor or motors can come from different sources which usually limits the machine range or operational time.

Machine supplying energy to the electric motor from the battery or rechargeable energy storage system (RESS) would be called battery electric vehicle (BEV). Within this powertrain machine uses the energy from the battery which needs to be recharged when minimal state of charge (SOC) is achieved. Therefore, size of the battery simply limits the operational time of the machine.

Other solution offers energy to the electric motor from different source of electricity, namely: fuel cell. Thus: fuel cell electric vehicle (FCEV). This option is based on the idea that electricity is supplied to the electric prime mover through chemical process. Hydrogen stored on a vehicle connects with the oxygen from the ambient air creating: electricity, heat and water. That kind of electric powertrain can be supplied with battery and plug-in option, however not necessarily $[1,2]$.

The third mentioned type of alternative non-road machinery powertrain supplies electric motor of the machine directly from the electric grid next to the working area. Within presented classification indicated as grid-EV. For machines working mainly stationary or within relatively small radius that solution seems to be rational. For more mobile machinery, e.g. agricultural tractor this solution might be a more of a challenge.

\subsection{Hybrid drive}

The definition of hybrid drive is a coexistence of primary and secondary drive within a vehicle. Most of the hybrid vehicle solutions consists of internal combustion engine (ICE) as a primary source of drive and electric motor with battery as a secondary drive. Many variants and configurations of the hybrid drives are possible, nevertheless two sources of drive to propel the vehicle is the definition of a hybrid drive $[1,2]$.

Variety of hybrid drives creates a need for systematization. Different criteria can be taken into account to do so, e.g. architecture or functional.

In terms of architecture hybrid drives can be divided as seen on Fig. 3:

1. Series hybrid drive: drive is supplied by electric motor using energy delivered by internal combustion engine to the battery,

2. Parallel hybrid drive: drive is supplied by internal combustion engine or/and electric motor,

3. Series-parallel hybrid drive: usage of advantages of both, series and parallel drive in order to transmit power and torque.

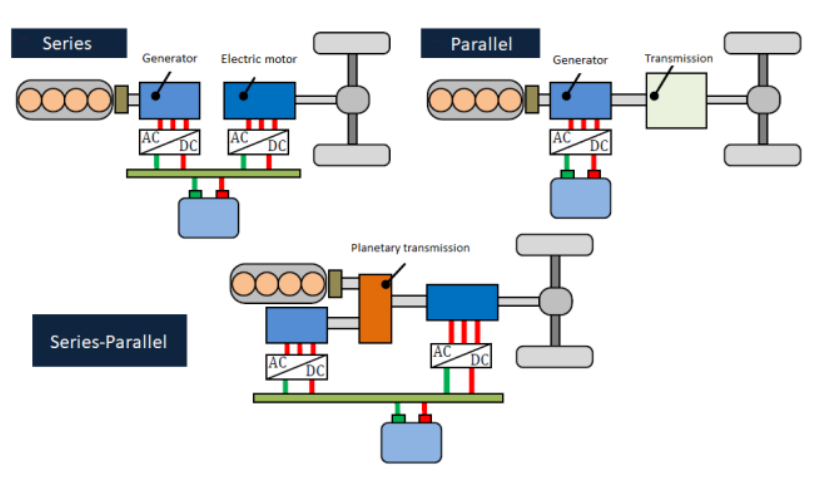

Fig. 3. Hybrid drive architectures [1]

In terms of functional features hybrid drives can be divided into:

1. Micro hybrid drive: the simplest hybrid drive, enables only start and stop of the internal combustion engine when operational parameters are suitable for that, uses only modified engine starting systems,

2. Mild hybrid drive: equipped with electric machine able to support internal combustion engine and recover energy from braking events,

3. Full hybrid drive: drive with full usage of internal combustion engine and electric machine as a motor and generator, simultaneous or separate work of both sources of drive is possible.

Important factor used to describe degree of hybridization of a powertrain is called the hybridization factor (HF) and is defined as a power of electric drives within the powertrain over sum of electric and internal combustion engine drive. According to the description above for microhybrid: $0<\mathrm{HF}<0.1$, mild hybrid: $0.1<\mathrm{HF}<0.25$, full hybrid: $0.25<\mathrm{HF}<0.5$, PHEV: $0.5<\mathrm{HF}<0.7$. The HF $=$ $=1$ refers to pure electric vehicle and $\mathrm{HF}=0$ to conventional non-hybrid powertrain.

One of the most common types of hybrid is hybrid electric vehicle (HEV). This solution is usually referred as internal combustion engine and electric motor with battery designed within one of the architectures mentioned earlier.

Another common solution is plug-in hybrid electric vehicle (PHEV) which is a extension of the HEV by adding possibility of charging a battery from external source (grid).

Specific solution of hybrid drive is range extender (REX). Idea of this drive is a small internal combustion 
engine with electric generator charging batteries only when needed, otherwise internal combustion engine does not operate. Separate electric motor supplies drive to the wheels $[1,2,4]$.

\section{Alternative powertrain - selected examples}

This paper does not encompass all types of alternative and especially hybrid drives available but just the ones encountered during the study of existing non-road machinery drives and selected as the most significant. Other types of alternative powertrain solutions as hydraulic hybrid vehicle (HHV) or photo-voltaic hybrid vehicle (PVEV) have not been recognized as significant examples in this study [18].

Description of existing examples of powertrain solution within classification in Fig. 2 will be carried out within this chapter.

\subsection{In-series drive}

Terex in 1974 presented Titan, a 320 tons dump truck. Equipped with 16-cylinder, approx. $2200 \mathrm{~kW}$ internal combustion engine and 10-pole AC generator supplying through rectifier DC voltage to the four electric traction motors [19].

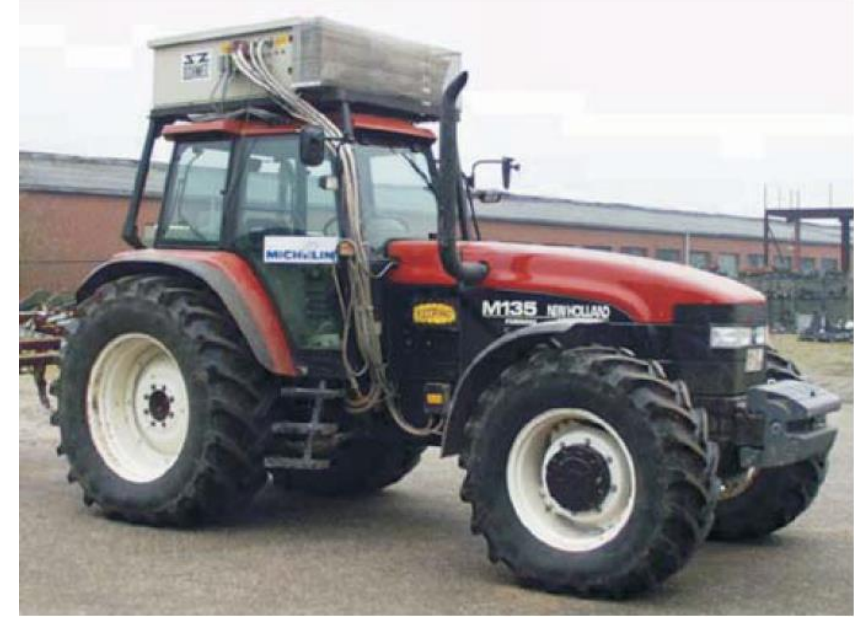

Fig. 4. Eltrac E 135 [20]

In 1998, Eltrac E135, first modern agricultural tractor with diesel-electric drive was built by Schmetz $\mathrm{GmbH}$ (shown in Fig. 4). Based on New Holland M135 with 6cylinder, turbocharged Iveco diesel with power of $100 \mathrm{~kW}$ and torque of $612 \mathrm{Nm}$. As shown in Fig. 5, air cooler electric generator supplied power to the electric motor which drive tractor gearbox [20].

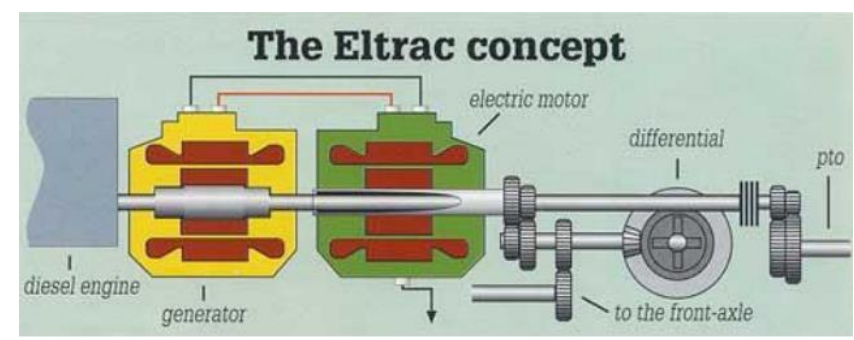

Fig. 5. Eltrac E 135 powertrain diagram [48]
Caterpillar, presented in Fig. 6. have also used dieselelectric drive in 2008 for their D7E bulldozer. Internal combustion engine of $175 \mathrm{~kW}$ drives an AC generator sending electric power to two traction motors [21]. Caterpillar claims fuel consumption reduction in this model in compare to its conventional predecessor D7R2 from $10 \%$ up to $30 \%$ [21].

The emissions of D7E in comparison to the conventional D7R2 appeared to range from $28 \%$ lower to $2 \%$ higher when it comes to $\mathrm{CO}_{2}$ and from $7 \%$ to $21 \%$ higher in terms of $\mathrm{NO}_{\mathrm{x}}$ [22].

In 2009 Belarus designed prototype of model 3023 as in Fig. 7. Diesel-electric with $220 \mathrm{~kW}$ diesel engine and 172 $\mathrm{kW}$ generator supplying power to transmission, electric engine fan drive, front PTO and $380 \mathrm{~V}$ power output sockets. Belarus claims $15 \%$ to $20 \%$ reduction in fuel consumption in comparison to its classical counterpart [23]. Plough field tests showed specific fuel consumption of $10.8 \mathrm{~kg} / \mathrm{h}$ for the diesel-electric powertrain and $13.2 \mathrm{~kg} / \mathrm{ha}$ for its conventional version. As result $18 \%$ of fuel consumption reduction has been proved [24].

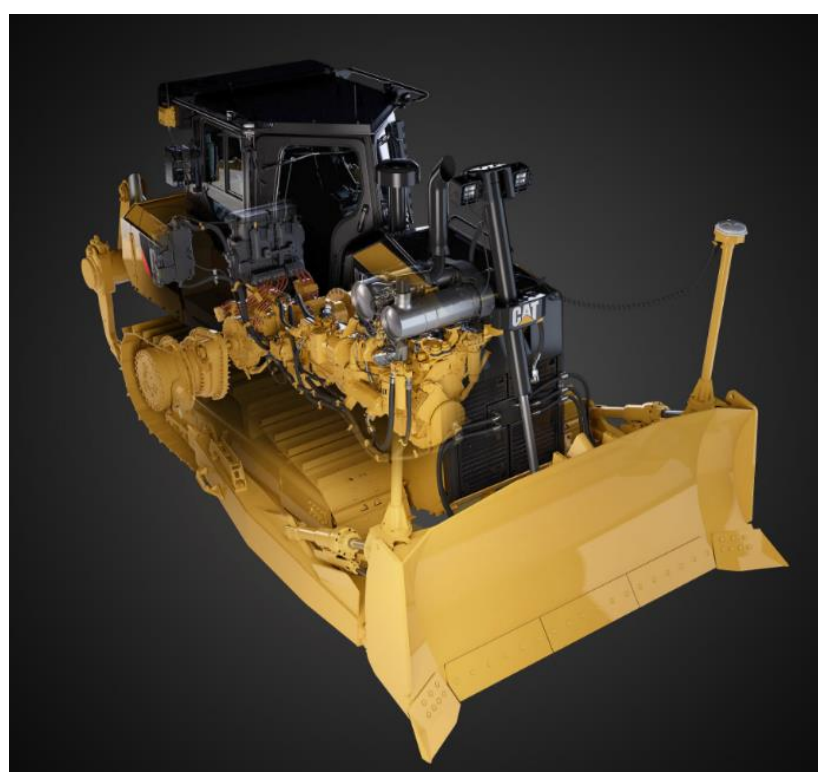

Fig. 6. Caterpillar D7E dozer [21]

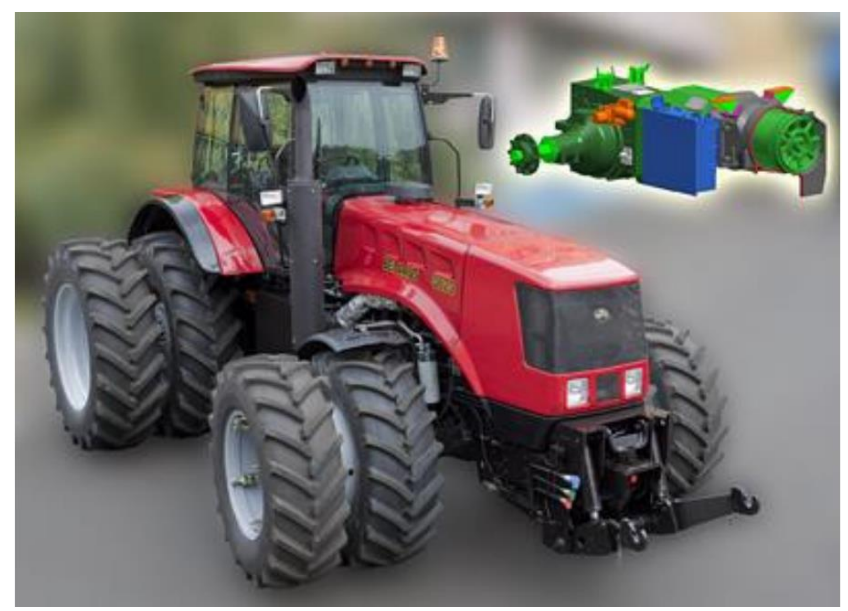

Fig. 7. Belarus 3023 with electro-mechanical powertrain [23] 
AGCO presented in 2010 self-propelled sprayer ElectRoGator 1386 with $229 \mathrm{~kW}$ CAT diesel engine supplying $650 \mathrm{~V}$ DC from the $200 \mathrm{~kW}$, water-cooled generator with $1500 \mathrm{rpm}$. Alternatively, $240 \mathrm{~kW}$ with $1900 \mathrm{rpm}$. Electric motors with $84 \mathrm{~kW}$ of power and $700 \mathrm{Nm}$ of torque mounted on each of four wheels (Fig. 8). Lifetime of the electric motors was estimated for $50,000 \mathrm{~h}$ which is longer than a lifetime of the traditional sprayer $[13,15]$.

AGCO claims that electric version o the sprayer featured $36 \%$ higher torque, $6 \%$ more power. On the prototype of the machine braking energy was dissipated into heat. Development works are conducted to recover this energy as well [23]. In comparison to conventional hydrostatic version, this electrified powertrain reduced fuel consumption in field tests from $20 \%$ in a summer up to $30 \%$ in autumn [13].

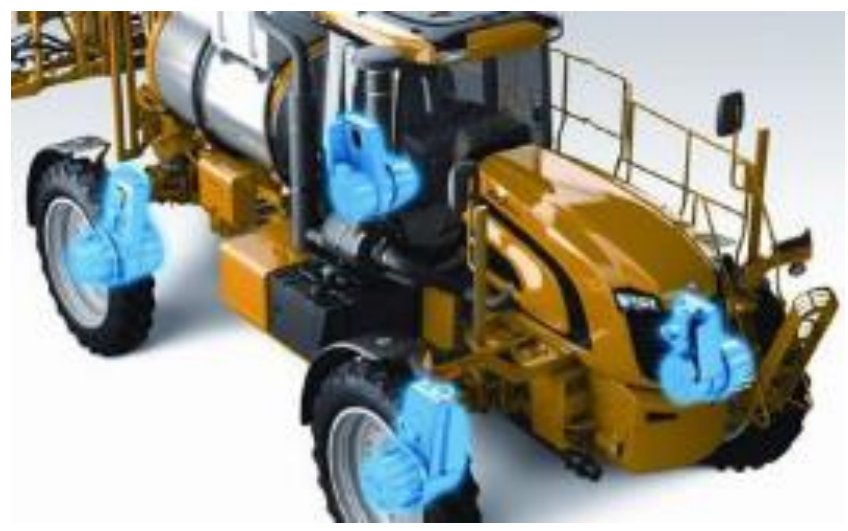

Fig. 8. AGCO ElectRoGator 1386 [23]

Swiss manufacturer Rigitrack together with Technische Universitat Dresden developed diesel-electric tractor EWD 120 (Fig. 9) equipped with $91 \mathrm{~kW}$ Deutz engine and $85 \mathrm{~kW}$, $650 \mathrm{~V} \mathrm{DC}$ liquid-cooled generator came to the public in 2011. Permanent magnet synchronous motors of $33 \mathrm{~kW}$ each mounted directly on wheels allowed to control torque transmission on each of axles as shown in Fig. 10. Additional electric output socket was available [17, 23].

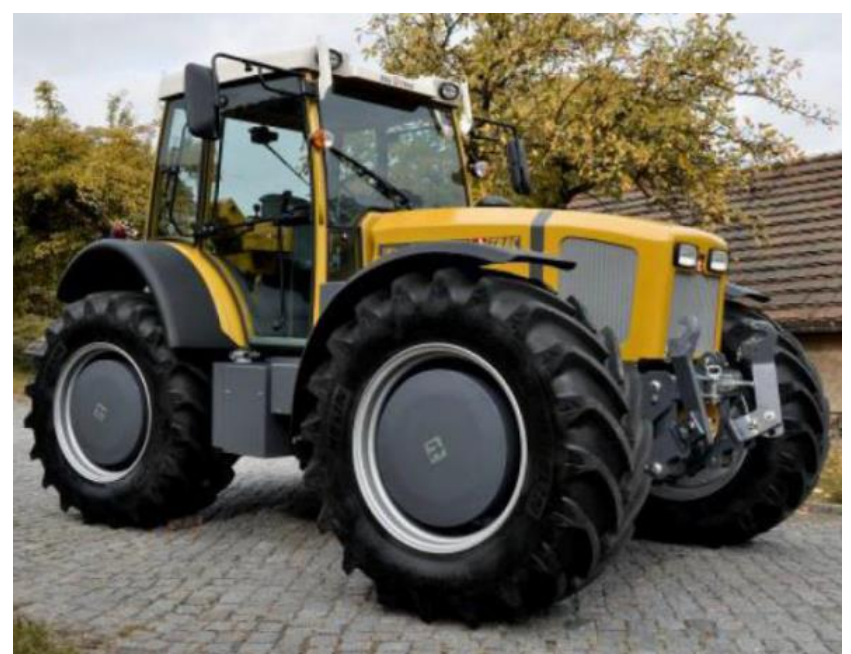

Fig. 9. Rigitrac EWD 120 [23]

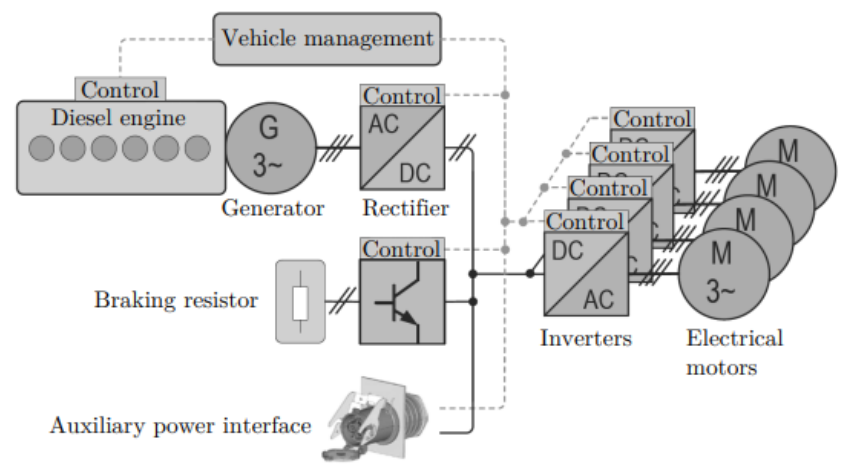

Fig. 10. Rigitrac EWD 120 powertrain architecture [52]

John Deere have introduced in 2013 loader 644K (Fig. 11) with their John Deere $6.8 \mathrm{dm}^{3}$, 6-cylinders diesel engine of $167 \mathrm{~kW}, 985 \mathrm{Nm}$ driving two brushless, oil-cooled AC generators. Electric power is further supplied through solid state, inverters to the four also brushless, oil-cooled AC motors, one for each wheel. Six inverters, one for each of the electric machines are based on insulated gate bipolar transistor (IGBT) technology.

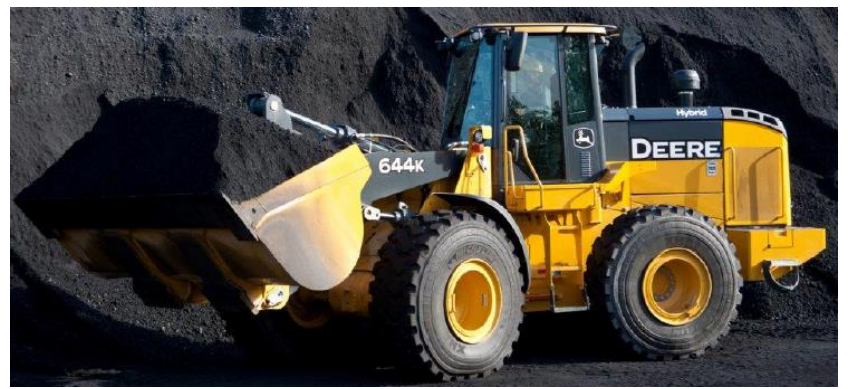

Fig. 11. John Deeer 644K Hybrid loader [27]

Powertrain does not feature energy store, but it is equipped in two water-cooled brake resistors to dissipate brake energy to be used for boom or bucket functions reducing load on the internal combustion engine and reducing fuel consumption (Fig. 12). Larger version of this machine is also available with similar powertrain architecture, model 944K [26]. John Deere claims $25 \%$ of fuel consumption reduction in comparison to the conventional powertrain of this machine $[23,27]$.

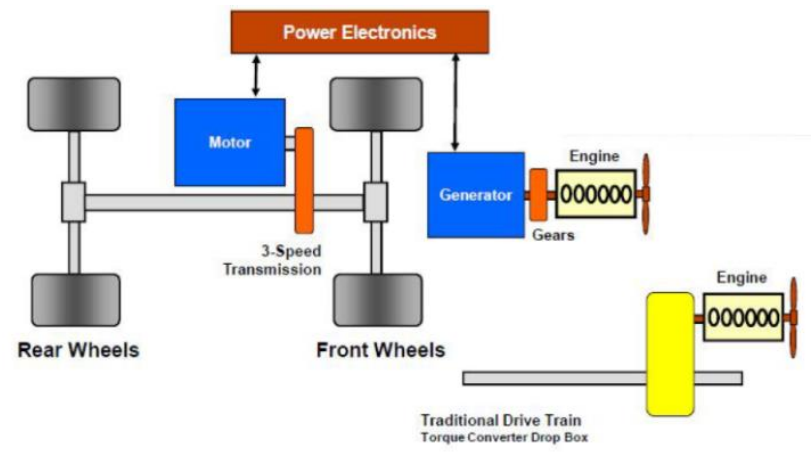

Fig. 12. John Deere 644K loader powertrain diagram, hybrid and traditionnal [27] 
In 2014 Belaz showed their 75710 (Fig. 13) dieselelectric dump truck. This also was the largest dump truck produced with 450 tons of payload prepared to work in difficult conditions and temperatures ranging from $-50^{\circ} \mathrm{C}$ to $+50^{\circ} \mathrm{C}$. Belaz put two $1704 \mathrm{~kW}$ alternators and connected them to four traction motors, $1200 \mathrm{~kW}$ each. Alternators driven by two diesel MTU DD 16V4000 engines with rated power of $1715 \mathrm{~kW}$.

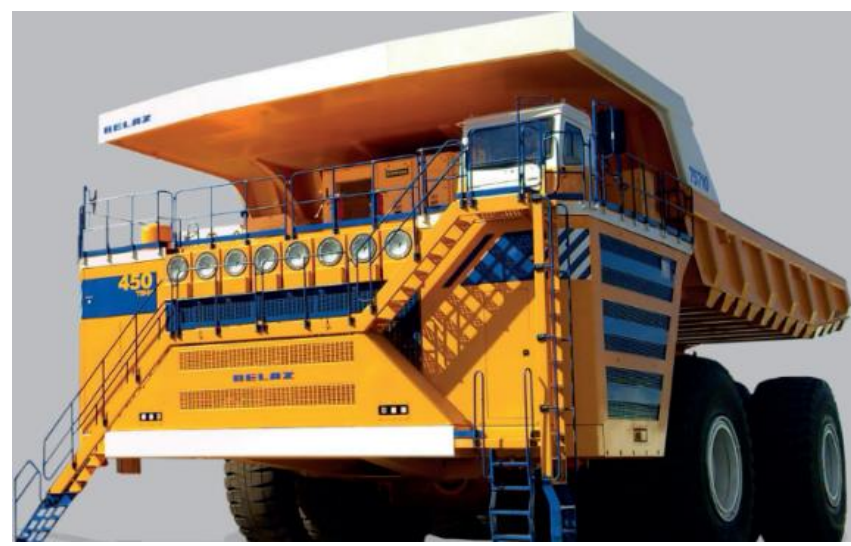

Fig. 13. Belaz 75710 [25]

\subsection{Electrified components drive}

In 1954 IH Farmall presented model IH ElectrAll as in Fig. 14. Regular agriculture tractor based on conventional powertrain architecture but with generator attached in parallel to the internal combustion engine ready to supply external receivers. Generator was a 3-phase, 120/208 V, $10 \mathrm{~kW}$ electric machine [14].

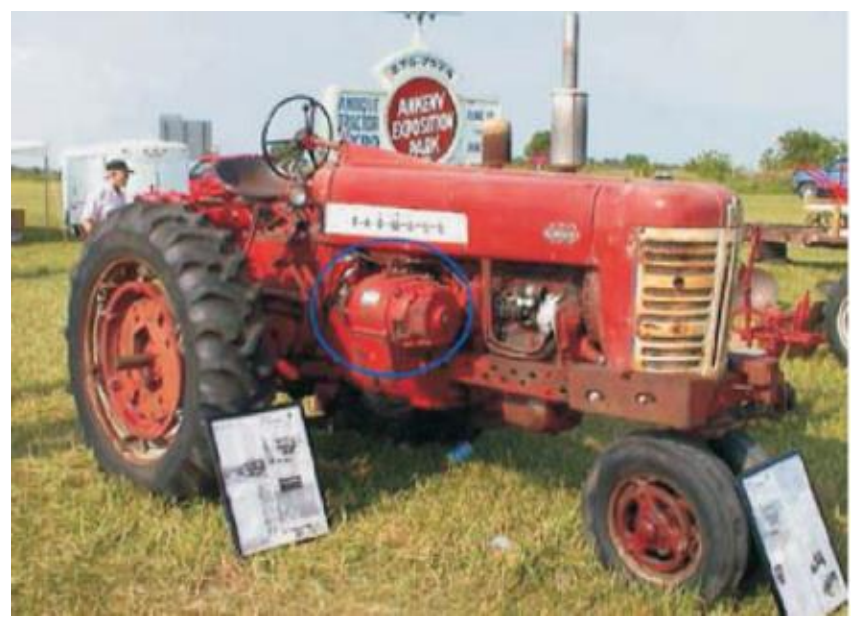

Fig. 14. IH Farmall 450 ElectrAll [14]

John Deere introduced in 2007 models 7430 E Premium and 7530 E Premium with standard $121 \mathrm{~kW}$ and $132 \mathrm{~kW}$ engines respectively. Tractors with conventional architecture featured additional 3-phase, $480 \mathrm{~V}, 20 \mathrm{~kW}$ electric generator mounted on an engine's fly wheel. Part of the electric power from the generator was consumed by electrically driven engine auxiliaries: radiator fan and $\mathrm{A} / \mathrm{C}$ compressor. This allowed precise control of duty time and speed of these devices. Additionally, electric energy is available on external sockets in a form of 1-phase $230 \mathrm{~V}$, and 3-phase, $400 \mathrm{~V}$ (Fig. 15). This power can be used to supply external devices up to $5 \mathrm{~kW}$ when tractor is standing still. Mentioned solution resulted in a $5 \%$ reduction in a fuel consumption in comparison to the conventional version of those machines [13, 15, 28].

Field tests of electrified and conventional version of 7530 tractor in harrowing and towing a trailer were conducted. Results yielded $4 \%$ of fuel consumption reduction in harrowing and $16 \%$ in towing a trailer on the road [29].

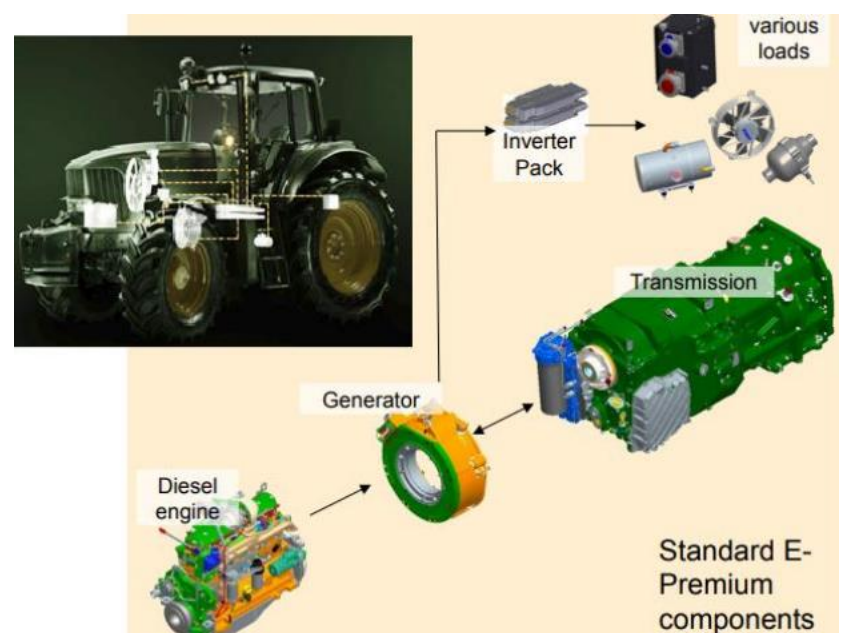

Fig. 15. John Deere 7530 E Premium components [30, 33]

Again, John Deere repeated similar solution and expanded its capabilities in 2011with model 6210 RE. This time architecture was similar to the solutions from 2007 however now $20 \mathrm{~kW}$ of electric power was available for driving external machines also when tractor was moving (Fig. 16). Available electric power parameters were $480 \mathrm{~V}$ DC and 3-phase, of $750 \mathrm{~V}$ AC with max. current of $200 \mathrm{~A}$ $[13,15,30,31]$.

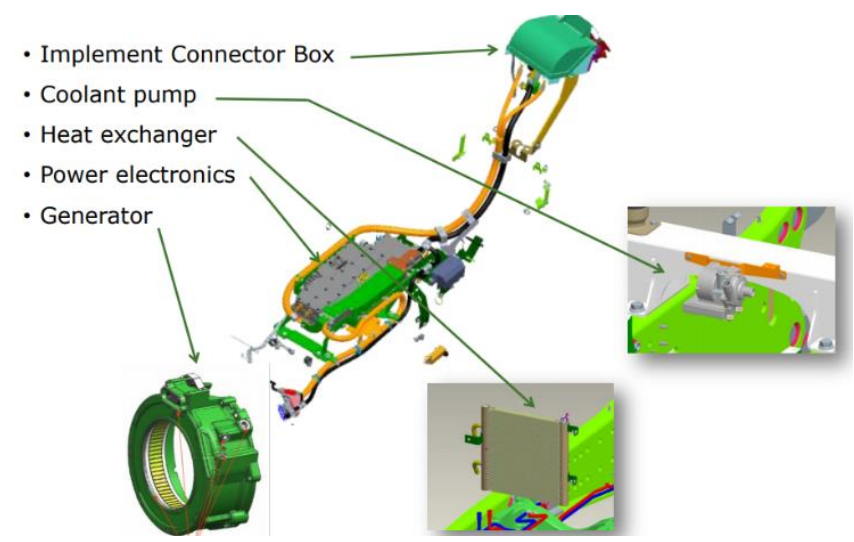

Fig. 16. John Deere 6210 RE powertrain components [30]

Similar solution was presented by Fendt in 2013 with model X Concept (Fig. 17) based on conventional Fendt 722 Vario with $147 \mathrm{~kW}$ diesel engine. Fendt has integrated AC generator o $130 \mathrm{~kW}, 700 \mathrm{~V}$ DC on the engine output supplying power to the engine auxiliaries: radiator fan and coolant pump and to the external sockets available to power implements [15, 23]. 


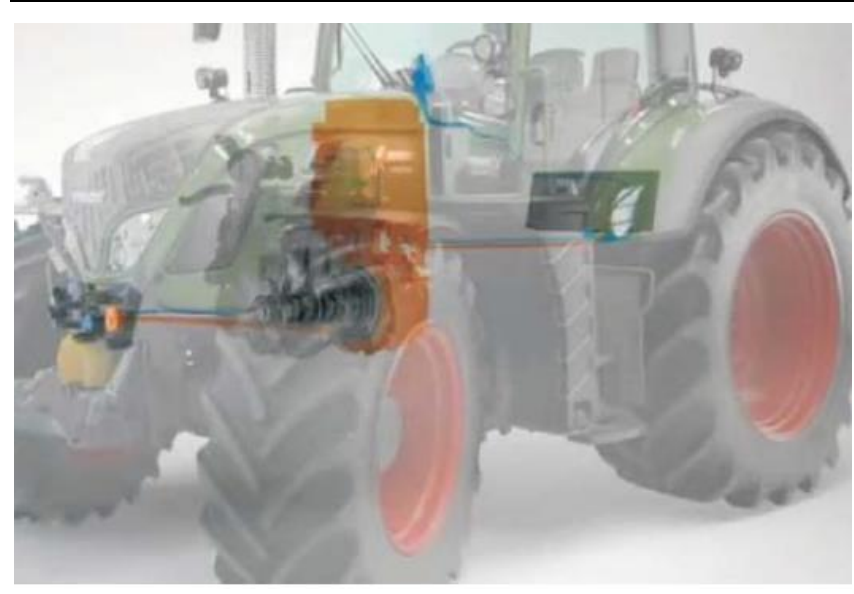

Fig. 17. Fendt X Concept powertrain components [15]

Other example of similar ready to use technology is a solution prepared by ZF with TERRA + product line ranging from 3-phase, $400 \mathrm{~V}$ electric motor hubs through $80 \mathrm{~kW}$ generators ready to be integrated between engine and a gearbox of existing machines to full size transmissions with $50 \mathrm{~kW}$ and $70 \mathrm{~kW}$ generators build in (Fig. 18). Generator is ready to supply energy to implements. Additionally, with deployment of energy store this can create hybrid system with recovery braking capabilities as presented in Fig. 19. The ZF also offers PTO driven generator to be fitted to the existing machine with capacity of supplying energy to two $25 \mathrm{~kW}$ electric motors [23, 32].

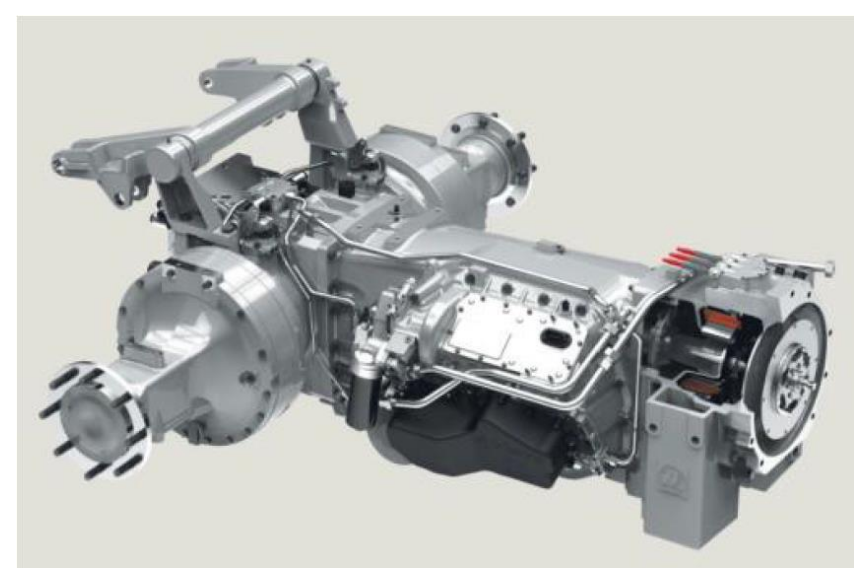

Fig. 18. ZF TERRA+ starter generator with transaxle [23]

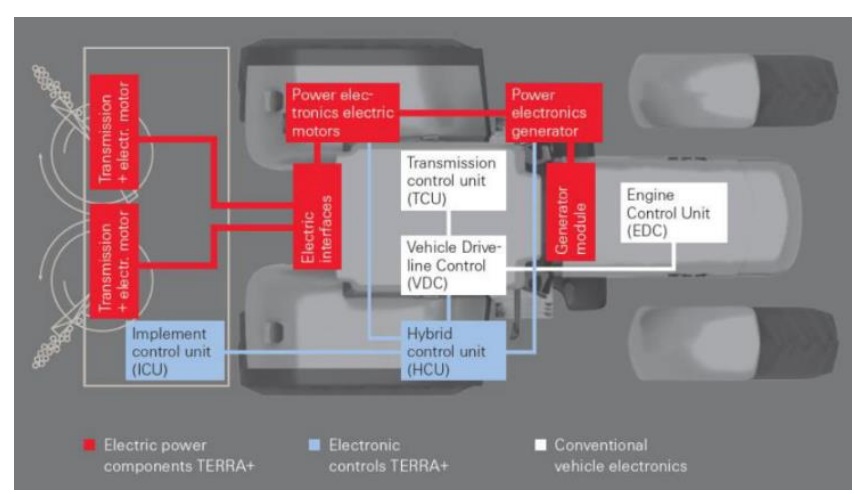

Fig. 19. ZF TERRA+ possible architecture [23]
In 2019 again John Deere presented new solution in their $8370 \mathrm{R}$ eAutoPowr as in Fig. 20. Based on regular tractor architecture with $275 \mathrm{~kW}, 6$-cylinder engine and continuously variable transmission (CVT). However, in this electrified solution hydraulic pump and motor have been changed for electric machines increasing significantly transmission efficiency. Additionally, AC brushless generator capable of supplying $100 \mathrm{~kW}$ power to the external implements through sockets on a back of the machine in a form of $700 \mathrm{~V} \mathrm{DC}$ or 3-phase, $480 \mathrm{~V} \mathrm{AC}$. Originally the project was developed together with trailer manufacturer Joskin to support their $100 \mathrm{~kW}$ electric motor mounted to the trailer axle [34, 35].

Taking into account that CVT not always supports machine with transmission efficiencies similar to the gear transmission this electrified option seems promising [23].

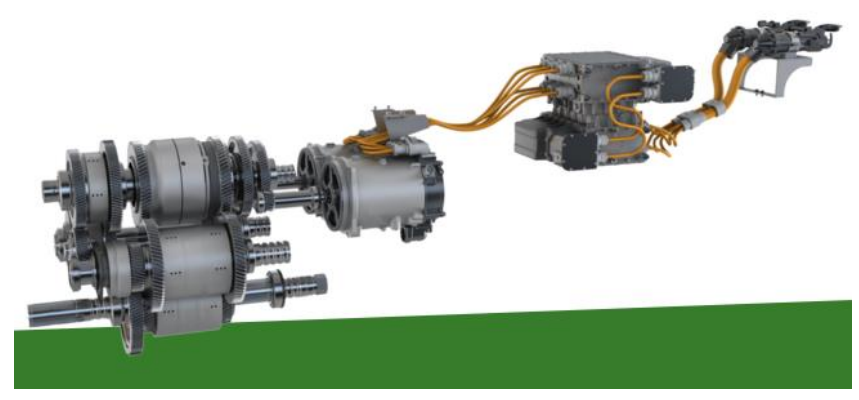

Fig. 20. John Deere eAutoPowr transmission [34]

\subsection{Electric drive}

In 1954 Alli-Chalmers presented first fuel cell powered electric tractor (Fig. 21). It featured 1008 cells arranged in 112 units of 9 cells each within 4 banks generating $15 \mathrm{~kW}$ of electric energy transferred to the electric drive motor.

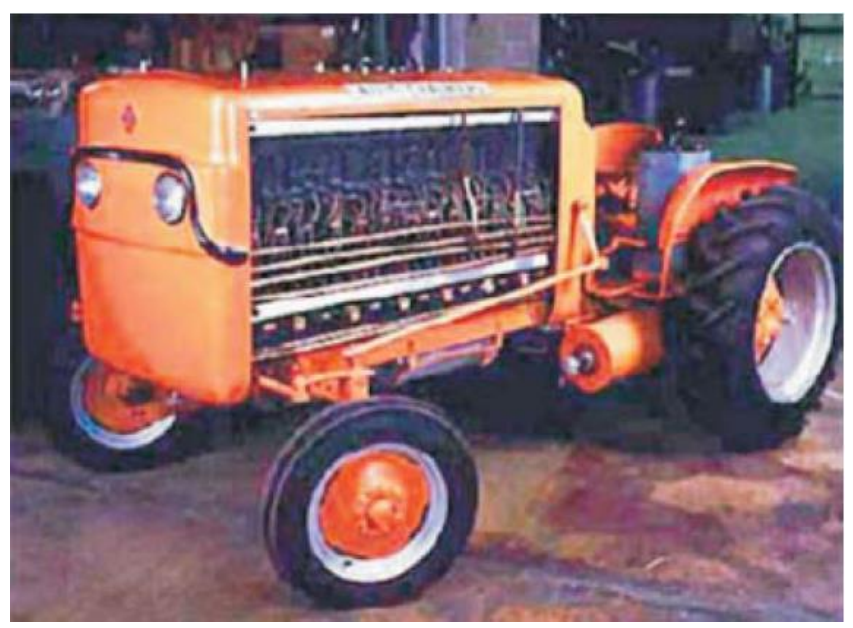

Fig. 21. Allis-Chalmers AC D-12 fuel cell tractor [14, 23]

First practical use of fuel cell electric vehicle (FCEV) in terms of tractor was presented by New Holland in 2011 (Fig. 22). Tractor named $\mathrm{NH}_{2}$ was based on conventional T6.140 model and featured fuel cell module of $100 \mathrm{~kW}$ with efficiency of $96 \%$ and 2 electric motors, one for PTO drive, other for tractor drive. Each motor performed 100 $\mathrm{kW}$ of power and $950 \mathrm{Nm}$ of torque. Quantity of $8.2 \mathrm{~kg}$ of hydrogen was stored under 350 bars of pressure. This 
powertrain solution featured a Li-Ion battery working with $300 \mathrm{~V}$ and size of $12 \mathrm{kWh}$ with peak power output of 50 $\mathrm{kW}[13,17,23]$.

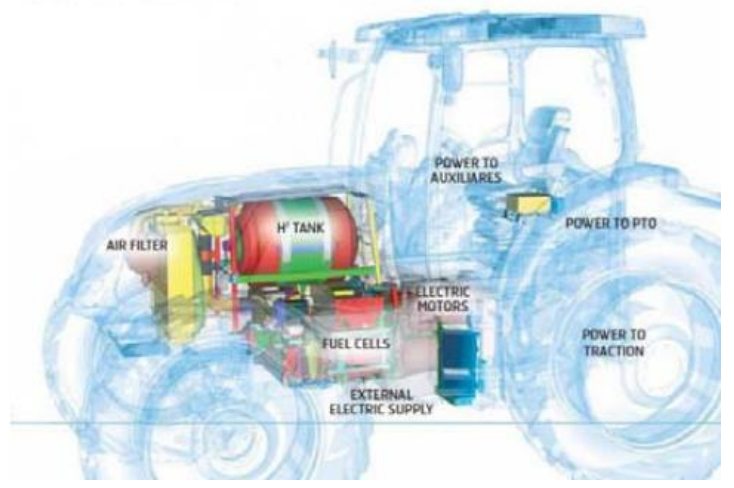

Fig. 22. New Holland NH2 hydrogen-powered tractor [23]

Proposition of prototype battery electric vehicle (BEV) was developed in 2016 by John Deere with a model called SESAM (Sustainable Energy Supply for Agricultural Machinery). Tractor was based on Mannheim's 6R frame and was equipped in $130 \mathrm{kWh}, 670 \mathrm{~V}$, Li-Ion battery and 2 electric motors $150 \mathrm{~kW}$ each (Fig. 23). One of the motors drives Direct Drive transmission and the second drives PTO. Tractor has capacity of work continuously for approx. $4 \mathrm{~h}$ or travel distance of $55 \mathrm{~km}$. Charging of the battery takes about $3 \mathrm{~h}$. Battery is designed for 3100 charging cycles $[12,36]$.

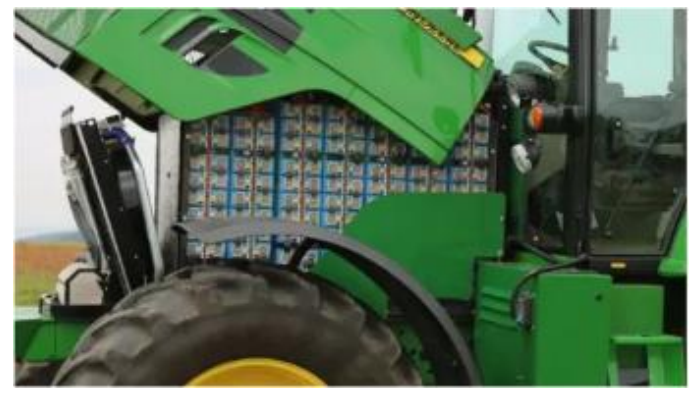

Fig. 23. Battery pack of John Deere SESAM [36]

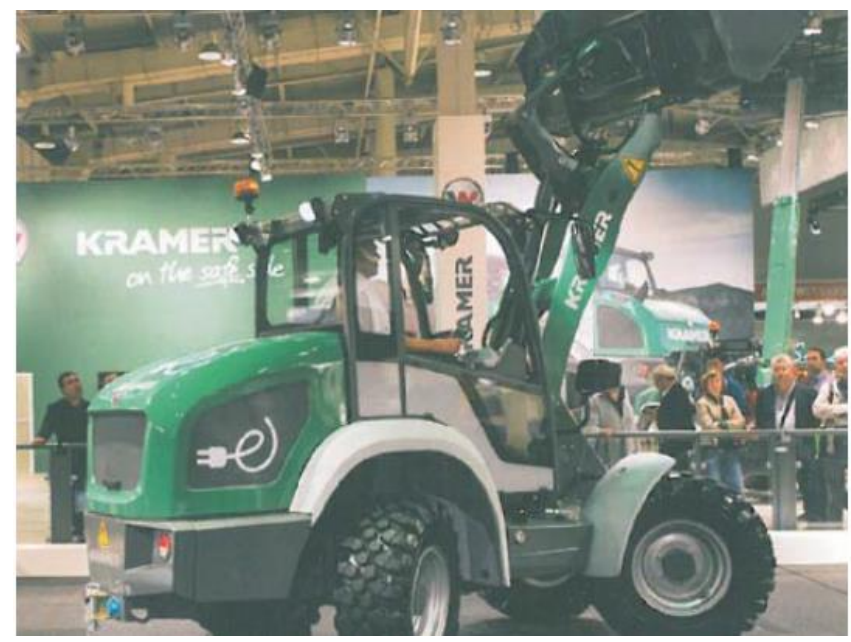

Fig. 24. Kramer 5055e loader [17]
In 2016 Kramer presented their first fully electric loader $5055 \mathrm{e}(\mathrm{BEV})$. It consists of 2 electric motors, one for the machine drive $15 \mathrm{~kW}$ and second for hydraulic drives $22 \mathrm{~kW}$ (Fig. 24). Battery works on $80 \mathrm{~V}$ and has capacity of $416 \mathrm{Ah}$. Operational time on one charging depends on load and range between $5 \mathrm{~h}$ and $8.5 \mathrm{~h}[17,37]$.

Next fully electric tractor shown by Fendt in 2017, model e100 Vario featured power output of $50 \mathrm{~kW}$ with LiIon battery of $100 \mathrm{kWh}$ and voltage of $650 \mathrm{~V}$ (Fig. 25). Operational time was estimated at $5 \mathrm{~h}$ under moderate load $[12,38]$.

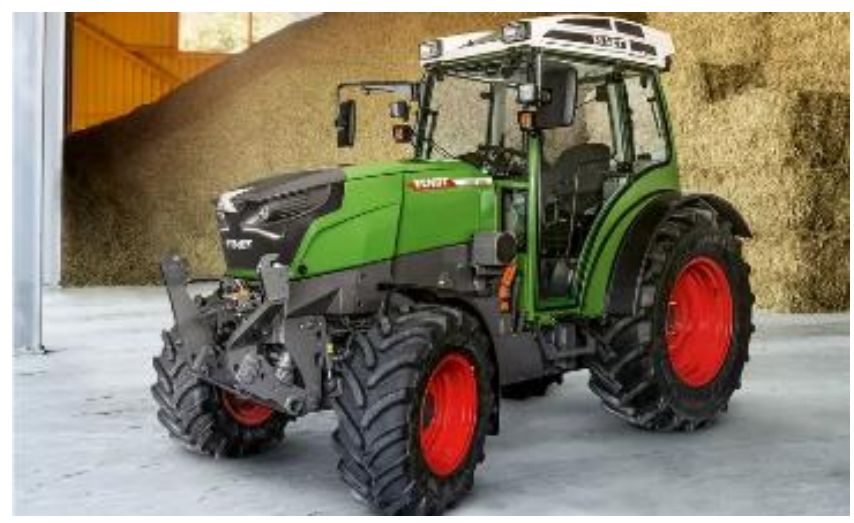

Fig. 25. Fendt e100 Vario [38]

Also, in 2017 Indian manufacturer Escorts launched its BEV tractor Farmtrac 26E prepared mainly for vineyards and horticulture presented in Fig. 26. In this solution electric motor of $19 \mathrm{~kW}$ drives standard transmission with $21 \mathrm{kWh}$, Li-Ion battery. This supports $6 \mathrm{~h}$ of working time [12].

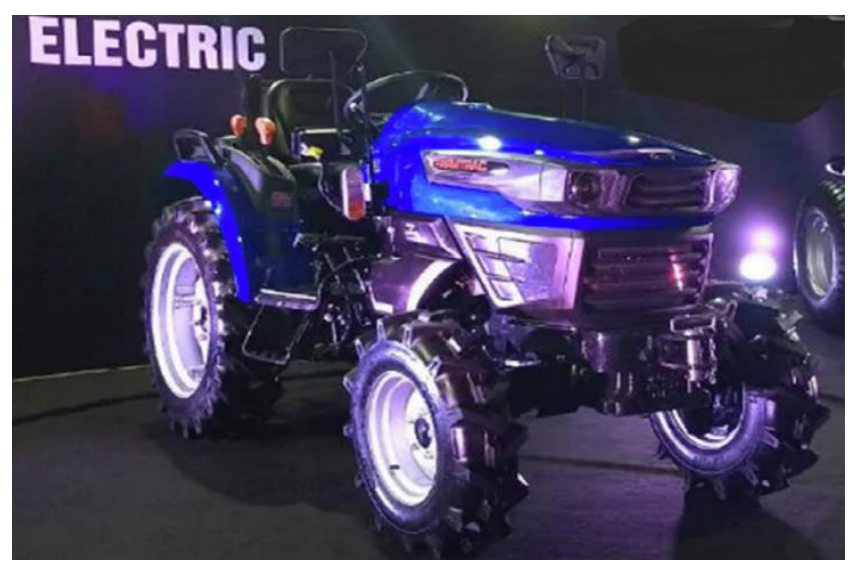

Fig. 26. Escorts Farmtrac 26E [12]

Very interesting solution for the electric vehicle (EV) have been proposed by John Deere in 2018. Autonomous tractor without the cab called GridCON with constant connection to the electric grid from the site of the field. Tractor is equipped with special spool with $1 \mathrm{~km}$ of supply cable mounted in a front of the machine as shown in Fig. 27. Mentioned cable supplies two electric motors, one $100 \mathrm{~kW}$ for tractor drive and second $200 \mathrm{~kW}$ for power output to the implement. Mass of the tractor is $8.5 \mathrm{t}$ which is an equivalent to the John Deere model 6195R. Max. speed of the machine is $20 \mathrm{~km} / \mathrm{h}$. Electric power supply need to be 2.5 
$\mathrm{kV}$ however tractor power bus is $700 \mathrm{~V}$ DC. John Deere claims that running costs of this powertrain solution are reduced by half in comparison to the BEV $[39,40]$.

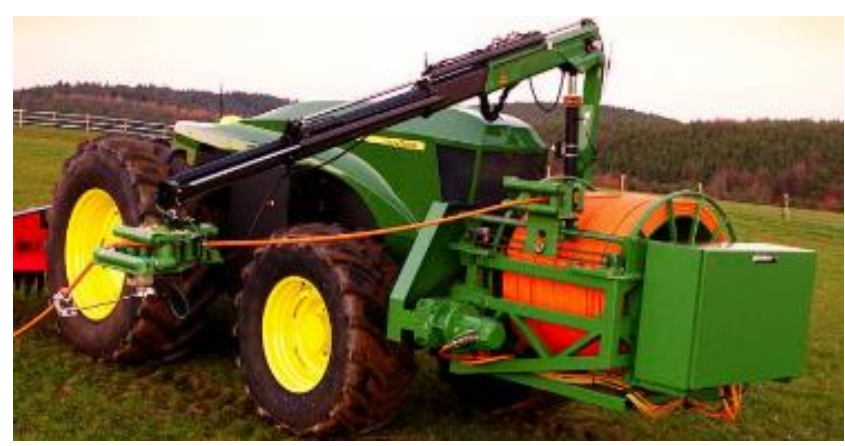

Fig. 27. John Deere GridCON [39]

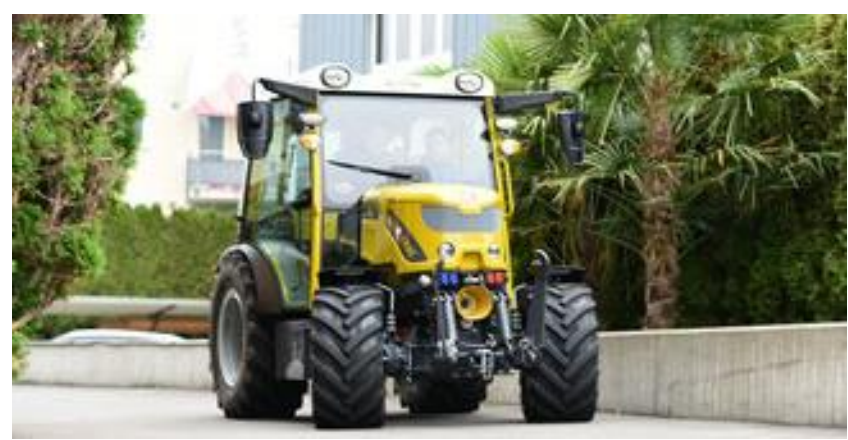

Fig. 28. Rigitrac SKE50 [41]

In 2019 Swiss manufacturer Rigitrac proposed new solution for the fully electric tractor BEV, model SKE 50 (Fig. 28). In this powertrain solution one Li-Ion, $400 \mathrm{~V}$, $80 \mathrm{kWh}$ battery supplies 4 electric motors, one for front axle, second for rear axle, third for front PTO and fourth for rear PTO [12, 41].

John Deere in 2019 shown two fully electric machines, with little information provided. First one, model 1RE, fully electric prototype of small compact tractor with expected operational time of $4.5 \mathrm{~h}$ on one charge (Fig. 29).

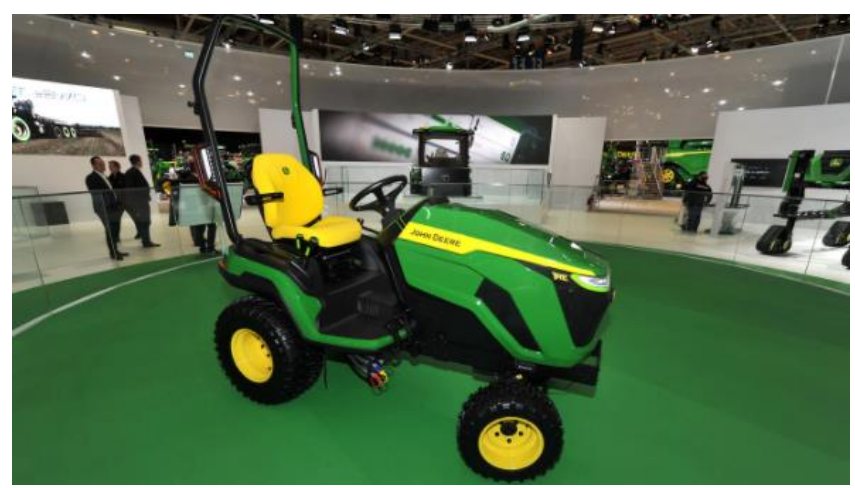

Fig. 29. John Deere 1 RE [42]

Second one is the John Deere Joker, prototype of fully electric and fully autonomous machine as in Fig. 30. Tractor is featuring no cab and power output of $500 \mathrm{~kW}$. No information about the battery have been provided yet [42].

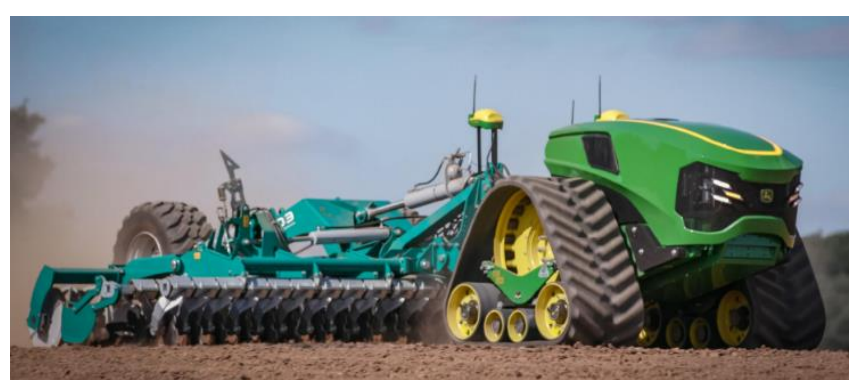

Fig. 30. John Deere Joker [40]

In 2020 Case and JCB showed their fully electric machines (BEV) for construction industry presented in Fig. 31. For Case that is "Project Zeus" 580 EV backhoe loader powered with $480 \mathrm{~V}, 90 \mathrm{~kW}$ Li-Ion battery pack supplying separately drive and hydraulic components. Single charge will support $8 \mathrm{~h}$ of operational time [43].

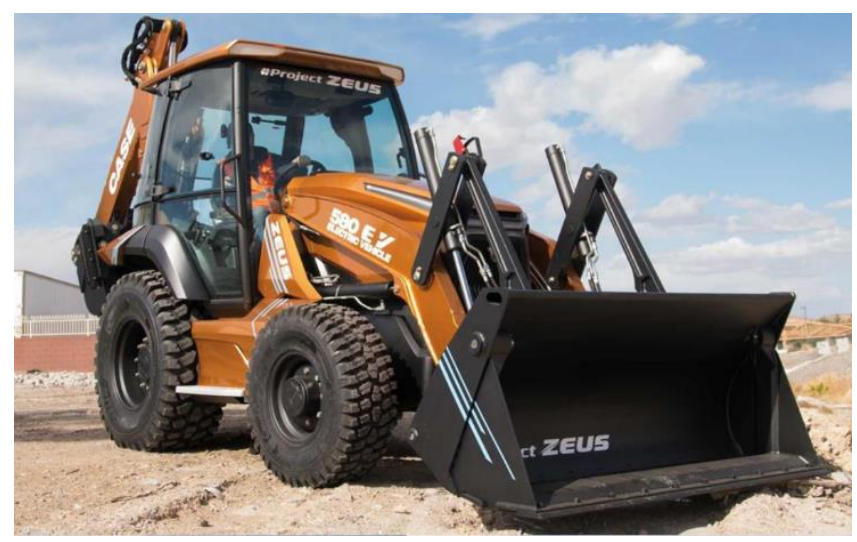

Fig. 31. Case 580 EV „Project Zeus” [43]

The JCB introduced whole fleet of construction battery electric vehicles. To name one: telehandler 525-60e (Fig. 32). With Li-Ion battery of $24 \mathrm{kWh}$ and 3 charging options: $110 \mathrm{~V}, 230 \mathrm{~V}, 415 \mathrm{~V}$. One charge supports entire day of operational time [44].

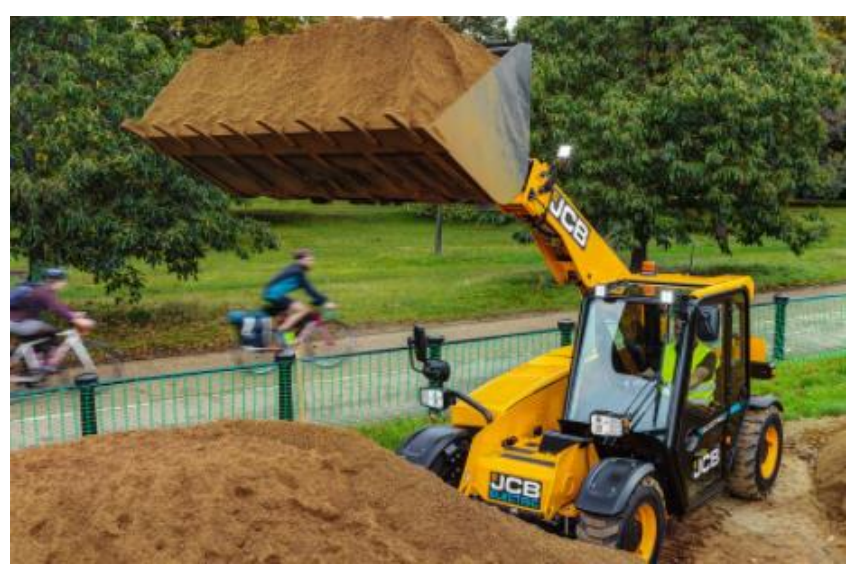

Fig. 32. JCB 525-60e telehandler [44]

John Deere in January 2021 also presented fully electric backhoe loader called E-power backhoe developed together with National Grid - an electricity and natural gas provider. 
The machine it is to perform on the same level as its conventional counterpart, model 310L [45].

In 2021, additionally to described developments, John Deere have already conducted field tests on autonomous machines working in swarm as in Fig. 33. In this particular example John Deere GridCON has supplied power to the single John Deere Joker machine. However, the idea is to supply energy to several machines [46, 47].

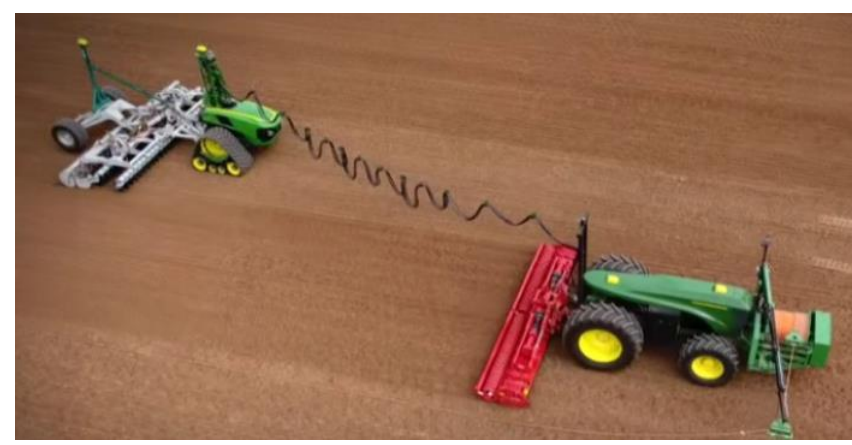

Fig. 33. John Deere GridCON and John Deere Joker [47]

\subsection{Hybrid drive}

First practical full hybrid electric (HEV) powertrain solution for non-road machinery was presented in 2005 Case ProHybrid EECVT (Fig. 34). Tractor based on conventional Case MXM with $120 \mathrm{~kW}, 800 \mathrm{Nm}$ engine and two electric machines, $50 \mathrm{~kW}$ each. One electric machine working as a generator supplies energy to the second one working as a motor. Surplus of energy can be stored in $11.5 \mathrm{kWh}, 456 \mathrm{~V}$ DC battery. Additionally, energy from braking can be recovered and sent to the battery. In this powertrain solution tractor can work in full electric mode or in a hybrid mode with diesel engine and electric motors together through CVT $[14,48]$.

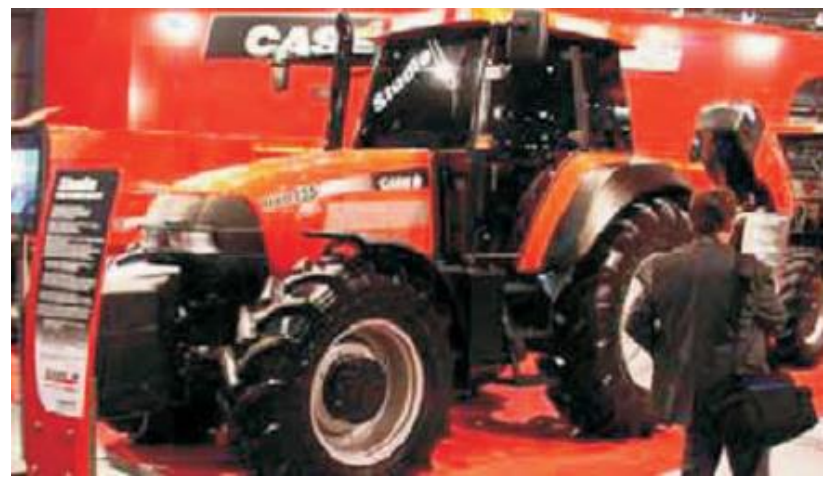

Fig. 34. Case ProHybrid EECVT [14]

In 2012, Komatsu introduced full hybrid (HEV) model HB205-1. Because of hybrid architecture diesel engine can be downsized form 6-cylinder to 4-cylinder. Electric generator/motor is placed at the engine output and supplies power to the capacitor as shown in Fig. 35. Electric swing motor/generator moves the upper structure of the machines and recovers energy from when the structure slows down sending it to capacitor. Energy from capacitor can be used to support the diesel engine by the means of motor/ generator placed on the engine output. Komatsu claims fuel consumption reduction between $25-41 \%$ [13, 23].

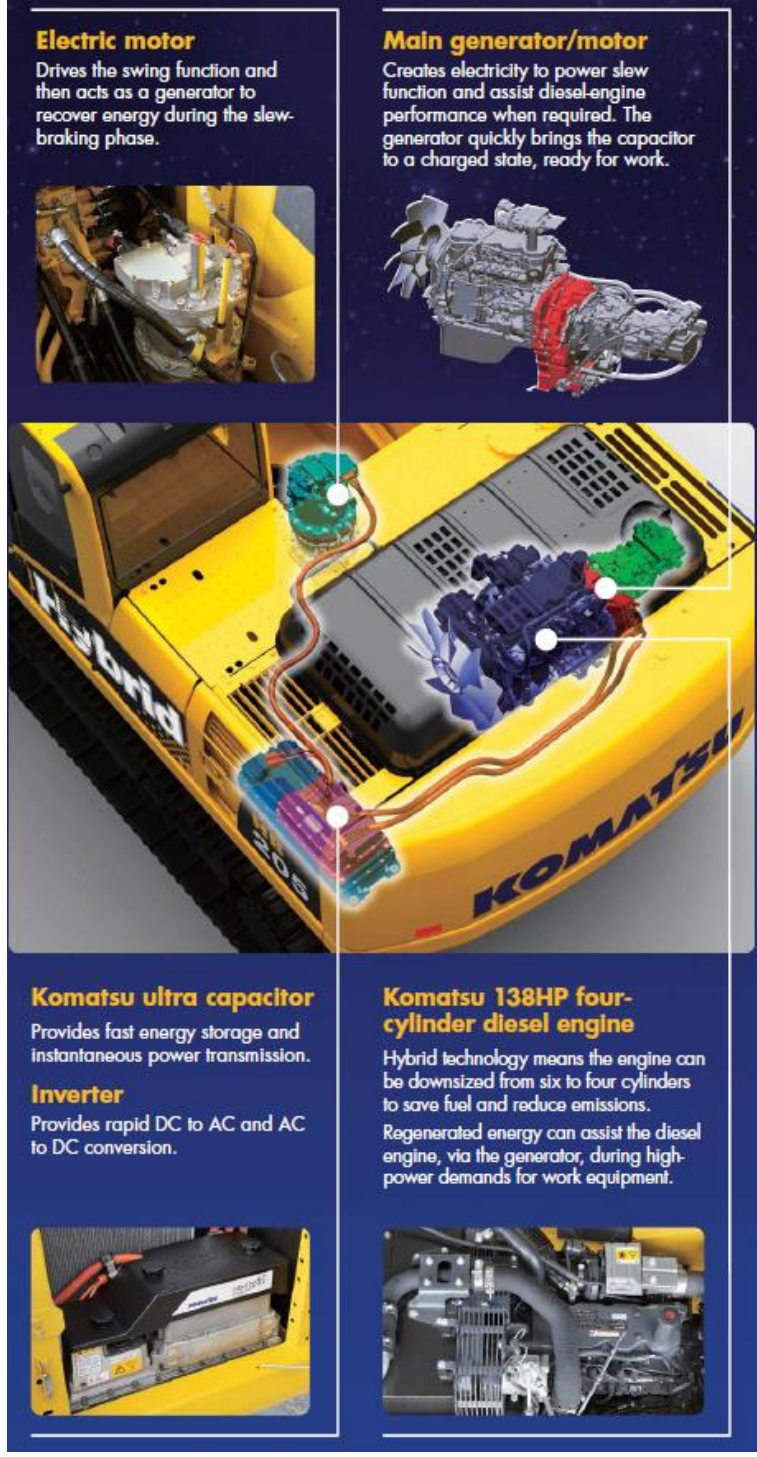

Fig. 35. Komatsu HB205-1 powertrain components [49]

Merlo presented in 2013 their 40.7 plug-in hybrid electric vehicle (PHEV). In fully electric mode the energy is supplied from $30 \mathrm{kWh}$, Li-Ion battery (Fig. 36). In hybrid mode internal combustion engine working at a constant speed supplies energy to the machine drive and charges the battery. In this architecture diesel output can be reduced in a half without the reduction in machine performance. In case of low-load work or idling, machine can work solely electric and reduce fuel consumption and $\mathrm{CO}_{2}$ emission up to $30 \%$ Merlo claims. Machine can be also charged from the grid as a plug-in hybrid $[17,48]$.

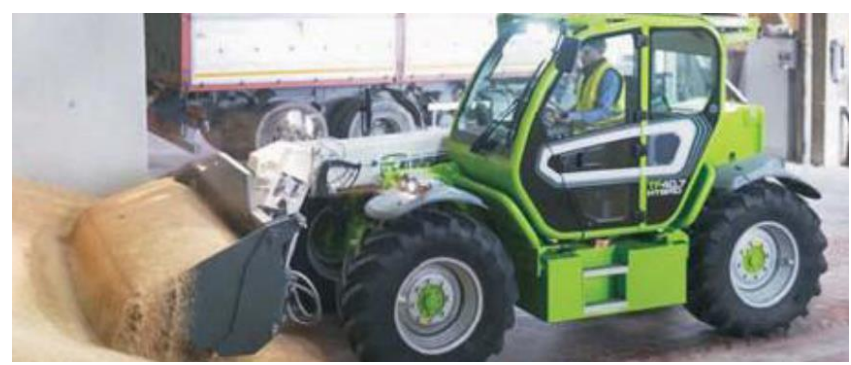

Fig. 36. Merlo 40.7 hybrid telehandler [48] 
Different type of hybrid vehicle (REX) used by Multi Tool trac company from Netherlands as in Fig. 37. This powertrain uses 6-cylinder, $160 \mathrm{~kW}$ diesel engine driving $140 \mathrm{~kW}$ generator supplying energy to the Li-Ion, $30 \mathrm{kWh}$ battery. This supports $0.5 \mathrm{~h}$ of continuous work. Electric energy is supplied from the battery to 4 electric motors at wheels [16].

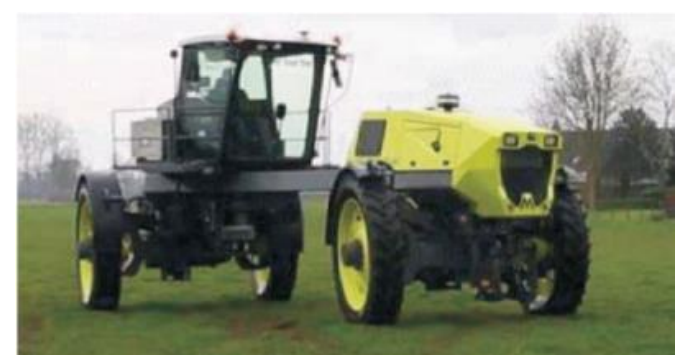

Fig. 37. Muli Tool Trac [16]

Claas have shown in 2016 full hybrid machine (HEV) based on model Arion 650. The Claas Arion 650 Hybrid. The prime mover in powertrain was a $129 \mathrm{~kW}, 6.8 \mathrm{dm}^{3}$ diesel engine driving $90 \mathrm{~kW}$ permanent magnet synchronous generator. The generator was located between engine and EQ200CVT transmission (Fig. 38). Second source of energy in this powertrain was $5.75 \mathrm{kWh}, 635 \mathrm{~V}$ battery $[16,50]$.

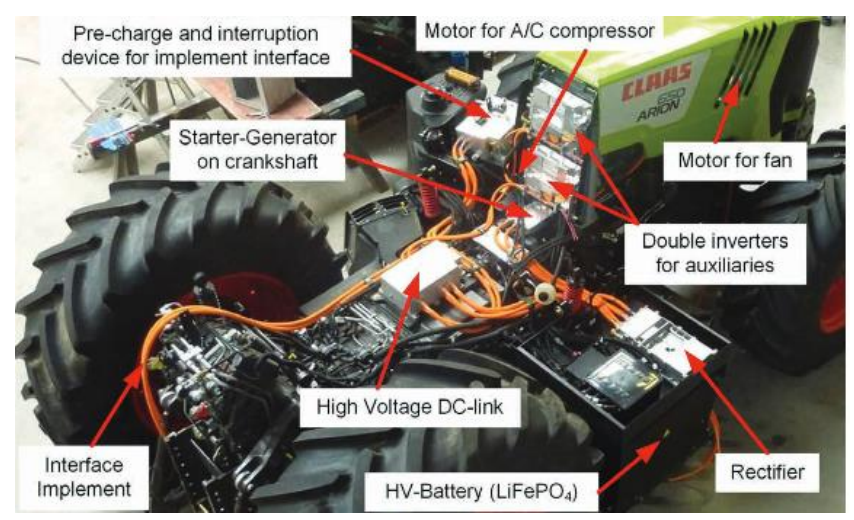

Fig. 38. Class Arion 650 Hybrid powertrain components [16, 50]

In 2019 Steyr presented its Konzept PHEV tractor as shown in Fig. 39. All hydraulics and PTO were electrically driven, external power output socket with $48 \mathrm{~V}$ and $700 \mathrm{~V}$ available as well. Energy from breaking was recovered and sent to battery. Charging from grid possible. Energy from the battery drives 4 electric motors at wheels [51].

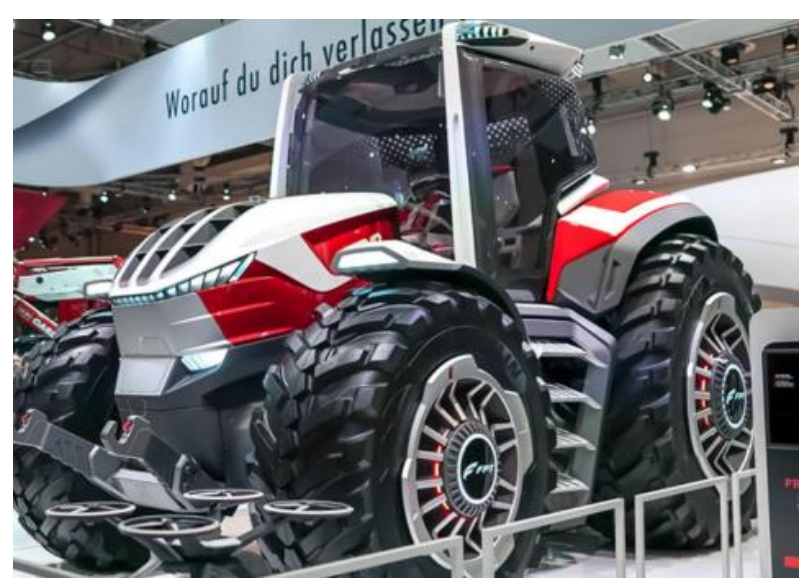

Fig. 39. Steyr Konzept [51]

\section{Conclusions}

In this paper main known alternative powertrain solutions within non-road machinery area have been presented. Classification for the mentioned examples have been undertaken and described. Together with indication of differences between given solutions. Based on that specific conclusions can be drawn:

1. Alternative powertrain solutions for non-road machinery are getting increasingly more attention, especially electric drives and start to play visible role within market of high tech solutions for this industry segment.

2. Significant rise in development works regarding alternative powertrain solutions started in early 2000 s and increased in 2010s.

3. Different structure within development works on alternative powertrain types over course of years is visible with direction moving from experimenting with many solutions to focus on the BEVs.

4. Many alternative powertrain solutions are not limited only to the machine powertrain but also expanded on supplying power to the implement as well.

5. Although pace of development works on alternative powertrains, mainly BEVs seems to be very fast, the limitations to the battery capacity therefore, operational time are still existing.

6. Alternative powertrains for non-road machinery are not making any significant impact on whole industry market now but mentioned pace of development works, also on battery technology puts this kind of solutions into near future perspective.

\section{Nomenclature}

$\mathrm{AC} \quad$ alternating current

$\mathrm{A} / \mathrm{C}$ air conditioning

BEV battery electric vehicle

CVT continuously variable transmission

DC direct current

EV electric vehicle

FCEV fuel cell electric vehicle

HEV hybrid electric vehicle

$\mathrm{HF}$ hybridization factor
HHV hybrid hydraulic vehicle

ICE internal combustion engine

IGBT insulated gate bipolar transistor

PHEV plug-in hybrid electric vehicle

PTO power take-off

PVEV photovoltaic electric vehicle

RESS rechargeable energy storage system

REX range extender

SOC state of charge 


\section{Bibliography}

[1] MERKISZ, J., PIELECHA, I. Układy mechaniczne pojazdów hybrydowych. Wydawnictwo Politechniki Poznańskiej. Poznań 2015.

[2] MERKISZ, J., PIELECHA, I. Układy elektryczne pojazdów hybrydowych. Wydawnictwo Politechniki Poznańskiej. Poznań 2015.

[3] RENIUS, K.T. Fundamentals of tractor design. Springer. 2020.

[4] Automotive Handbook. Robert Bosch GmbH. 2014.

[5] RYMANIAK, Ł., LIJEWSKI, P., KAMIŃSKA, M. et al. The role of real power output from farm tractor engines in determining their environmental performance in actual operating conditions. Computers and Electronics in Agriculture, 2020 173, 105405. https://doi.org/10.1016/j.compag.2020.105405

[6] Regulation (EC) No 443/2009 of the European Parliament and of the Council of 23 April 2009 setting emission performance standards for new passenger cars as part of the Community's integrated approach to reduce $\mathrm{CO}_{2}$ emissions from light-duty vehicles.

http://eur-lex.europa.eu/legal-

content/EN/ALL/?uri=celex\%3A32009R0443

[7] Regulation (EU) 2016/1628 of the European Parliament and of the Council of 14 September 2016 on requirements relating to gaseous and particulate pollutant emission limits and typeapproval for internal combustion engines for non-road mobile machinery, amending Regulations (EU) No 1024/2012 and (EU) No 167/2013, and amending and repealing Directive 97/68/EC.

http://eur-lex.europa.eu/legal-content/EN/TXT/PDF/? uri=CELEX:32016R1628\&from $=$ LV

[8] European Stage V non-road emission standards. International Council of Clean transportation. 2016.

http://theicct.org/sites/default/files/publications/EU-StageV_policy\%20update_ICCT_nov2016.pdf

[9] FEBIG, M., WIARTALLA, A., HOLDERBAUM, B. et al. Particulate emissions from diesel engines: correlation between engine technology and emissions. Journal of Occupational Medicine and Toxicology. 2014, 9(6). https://doi.org/10.1186/1745-6673-9-6

[10] CWIKOWSKI, P., TEODORCZYK, A. The latest achievements in gasoline and diesel injection technology for the internal combustion engines. Journal of KONES Powertrain and Transport. 2009, 16(2), 79-90.

http://yadda.icm.edu.pl/yadda/element/bwmeta1.element.baz tech-article-BUJ5-0032-0016

[11] DZIUBINSKI, M., DROZD, A., ADAMIEC, M. et al. Energy intensity of the electric vehicle. Advances in Science and Technology Research Journal. 2017, 11(4), 27-34. https://doi.org/10.12913/22998624/78516

[12] MALIK, A., KOHLI, S. Electric tractors: survey of challenges and opportunities in India. Materials Today: Proceedings. 2020, 28, 2318-2324. https://doi.org/10.1016/j.matpr.2020.04.585

[13] MOREDA, G.P., MUNOZ-GARCIA, M.A., BARRIEIRO, P. High voltage electrification of tractor and agricultural machinery - a review. Energy Conversion and Management. 2016, 115, 117-131. https://doi.org/10.1016/j.enconman.2016.02.018

[14] WEYMANN, S. Electric drivelines for tractors and agricultural machinery. Part 1. Agricultural, Horticultural and Forest Engineering. 2016, 61(4), 6-8.

[15] WEYMANN, S. Electric drivelines for tractors and agricultural machinery. Part 2. Agricultural, Horticultural and Forest Engineering. 2016, 61(5), 8-10.
[16] WEYMANN, S. Electric drivelines for tractors and agricultural machinery. Part 3. Agricultural, Horticultural and Forest Engineering. 2016, 61(6), 9-11.

[17] WEYMANN, S. Electric drivelines for tractors and agricultural machinery. Part 4. Agricultural, Horticultural and Forest Engineering. 2017, 62(1), 11-14.

[18] MOUSAZADEH, H., KEYHANI, A., JAVADI, A. et al. Optimal power and energy modeling and range evaluation of a solar assist plug-in hybrid electric tractor (SAPHT). American Society of Agricultural and Biological Engineers. Transactions of the ASABE. 2010, 53(4), 1025-1035.

https://doi.org/10.13031/2013.32586

[19] DREW, D. Terex Titan. It was a big one. Earthmovers Magazine. http://www.earthmoversmagazine.co.uk/digger$\mathrm{man} / \mathrm{view}$, terex-titan-it-was-the-big-one-blog-postrevisited_252.htm (accessed on 10.06.2021).

[20] BERNHARD, B. Untersuchungen zur Bewegung Stufenloser Fahrantriebe für Mahdrescher. Universitat Hochenheim. 2011.

http://opus.uni-hohenheim.de/volltexte/2012/648/pdf/Dissertation_Bjoern_Bernhard.pdf

[21] Caterpillar trade press media representatives. Updated Cat D7E features advanced technology to boost productivity. 2014. http://www.cat.com/en_GB/news/machine-pressreleases/updated-cat-d7e-featuresadvancedtechnologytoboostproductivityand.html (accessed on 10.06.2021).

[22] JOHNSON, K.C., BURNETTE, A., CAO, T. et al. Hybrid off-road equipment in-use emission evaluation. FY 2010-11 air quality improvement project. Hybrid off-road equipment pilot project. California Air Resources Board. 2013.

[23] HOY, R., ROHRER, R., LISKA, A. et al. Agricultural industry advanced vehicle technology: Benchmark study for reduction in petroleum use. Idaho National Laboratory. 2014.

[24] PUHOVOY, A.A. Agricultural tractor with pure electromechanical drivetrain. SAE International Journal of Commercial Vehicles. 2011, 4(1), 275-285. https://doi.org/10.4271/2011-01-2296

[25] Belaz.

http://belaz.by/en/products/products-belaz/dumpers/dumptrucks-with-electromechanical-transmission/dumpers-series7571/ (accessed on 10.06.2021).

[26] Construction Equipment. http://www.constructionequipment.com/john-deere-644khybrid-wheel-loader (accessed on 10.06.2021).

[27] SOBOTZIK, J. Electrische Antriebstechnik. Eine neue Chance in Mobile Arbeitmaschinen. VDI Workshop Electrification. Wieselburg. 2013.

[28] HAHN, K. High voltage electric tractor-implement interface. SAE International Journal of Commercial Vehicles. 2009, 1(1), 383-391. https://doi.org/10.4271/2008-01-2660

[29] PESSINA, D., FACCHINETTI, D. Gemelli diversi. Macchine Agricole. 2009, 7, 44-51.

http://www.researchgate.net/publication/303142160_Gemell i_diversi

[30] KRAH, J.O., SOBOTZIK, J., HAMBLOCH, M. Tractor/implement electrification. Opportunities and challenges. EtherCat in Mobile Applications. Frankfurt. 2013.

[31] STOSS, K.J, SHI, B., SOBOTZIK, J. et al. Tractor power for implement operation - mechanical, hydraulic, and electrical: An overview. Agricultural Equipment Technology Conference, Kansas City. 2013.

[32] BUNING, E.A. Electric drives in agricultural machinery. An approach from the tractor side. Bologna, EIMA International, 2015. 
[33] MUNCH, P. Sensorik und Elekrifirizierung bei Landmachinen. John Deere. 2013.

[34] Eautopowr Eroffnet neue Traktorbe-triebsweisen. http://flurundfurche.de/eautopowr-eroeffnet-neuetraktorbetriebsweisen/ (accessed on 10.06.2021).

[35] Das Gullefass Arbait mit. http://www.deere.de/de/blog/articles/technik/eautopowrjohn-deere-elektrisches-getriebe-power-off-boarding/ (accessed on 10.06.2021).

[36] John Deere SESAM-batterie-traktor. http://www.topagrar.com/technik/news/john-deere-sesambatterie-traktor-9365391.html (accessed on 10.06.2021).

[37] Into the future with new drive. http://www.kramer-online.com/en/product/model/5055e/ (accessed on 10.06.2021).

[38] Fendt e100 Vario. Unser antrieb fur the zukunft. http://www.fendt.com/at/e100-vario (accessed on 10.06.2021).

[39] An der Langen Leine. http://www.faz.net/aktuell/technikmotor/motor/john-deere-forscht-am-elektrischen-traktor15961820.html (accessed on 10.06.2021).

[40] PICKEL P. Trends in tractor development. John Deere ETIC. Wieselburg. 2020

[41] Rigitrac Traktorenbau AG. http://www.rigitrac.ch/produkte1/rigitrac-ske-40-electric/ (accessed on 10.06.2021).

[42] Future of farming. http://www.deere.co.uk/en/agriculture/future-of-farming/ (accessed on 10.06.2021).

[43] The industry's first fully electric backhoe loader-The Case $580 \mathrm{EV}$ http://www.casece.com/northamerica/en-

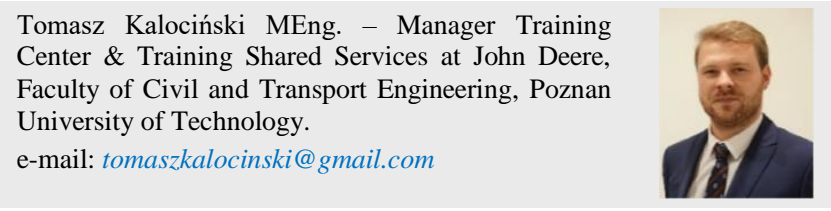

us/products/backhoe-loaders/580ev-project-zeus (accessed on 10.06.2021).

[44] The new electric JCB 525-60e compact telehandler. http://www.jcb.com/en-gb/products/telescopic-handlers/52560e-hi-viz (accessed on 10.06.2021).

[45] John Deere joint its first electric powered backhoe with National Grid. http://www.deere.com/en/ourcompany/news-and-announcements/newsreleases/2021/construction/2021jan06-electric-poweredbackhoe/ (accessed on 10.06.2021).

[46] The autonomous swarm tractor from John Deere. http://thefurrow.co.uk/the-autonomous-swarm-tractor-fromjohn-deere/ (accessed on 10.06.2021).

[47] Farmer.pl http://www.farmer.pl/technika-rolnicza/maszynyrolnicze/ciagnik-na-prad-z-przewodu-john-deerezadziwia, 108905.html (accessed on 10.06.2021).

[48] CABAN, J., ZARAJCZYJ, J., SZMIGIELSKI, M. et al. Hybrid drive as a future in agricultural technology. Proceedings of the Institute of Vehicles. 2018, 3(177), 19-27.

[49] Komatsu customer support materials. Komatsu hybrid excavator. World-first hybrid technology. http://www.komatsu.com/ (accessed on 10.06.2021).

[50] TETZLAFF, S. System-wide electrification and appropriate functions of tractor and implement. Landtechnik. 70(5), 203216. 2015. http://doi.org/10.15150/lt.2015.2676

[51] Steyr traktoren. http://www.steyr-traktoren.com/endistributor/agriculture/technologie/steyr-konzept (accessed on 10.06.2021).

[52] OSINENKO, P. Optimal slip control for tractors with feedback of drive torque. Technische Universitat Dresden. 2014. 